\title{
Flexural Behavior of High Strength Concrete Incorporated Super Absorbent Polymer (SAP)
}

\author{
Suhad Mohammed Abd, Baidaa Khdheer \\ Department of Civil Engineering, Engineering College, University of Diyala \\ Baidaakhdheer@gmail.com
}

\begin{abstract}
This research include the study of flexural behavior of reinforced concrete beams with and without addition of super absorbent polymer (SAP) to concrete, two groups of concrete mixture were used; each one have five concrete mixture (Reactive Powder Concrete RPC, Modified Reactive Powder Concrete, Self Compact Concrete SCC, High Strength Concrete HSC and Normal Strength Concrete NSC) four of them with high compressive strength and the last one with normal compressive strength. Group A casting concrete without addition of SAP, group B casting concrete with addition of SAP. Ten beams are molded of $(200 * 300 * 1700) \mathrm{mm}$ dimension with same steel reinforcement. Flexural tested for all beams was doing and load-deflection relationships of beams with and without SAP were established. Test results had shown that beams casting with addition of SAP (group B) proved to have larger load carrying capacity and llower deflection compared with group A.
\end{abstract}

Keywords: Flexural behavior, High-Strength Concrete, Superabsorbent Polymer, Internal Curing IC.

Paper History: Received: (2/1/2017), Accepted: (9/4/2017)

\section{Introduction}

High strength concrete HSC with a low watercement ratio has become widely used in the last decades, it needs particular curing to complete hydration process so addition of super absorbent polymer (SAP) as internal curing and its effect on flexural behavior of high strength reinforced concrete beams studied in this research. In engineering, deflection is the degree to which a structural element is displaced under a load, to improve this behavior, it is necessary to use internal curing to concrete to ensure the complete of cementation material hydration and reduuce of self-desilcation, the phenomena that occurs in high strength mixes of concrete due to insufficient internal curing, in this study SAP is used as internal curing material. Super absorbent polymer (SAP) is one of the most important materials in modern polymer technology $(1,2)$, it can absorb hundreds milliliters (ml) of water per gram of its weight. The purpose of this study is to experimentally evaluate the effect of SAP as internal curing agent in order to increase the applied load and decrease the deflection of beams by complete the hydration of cement material, after SAP particle absorb the external water during mixing of concrete, the water released from SAP to continue the hydration of cement, i.e producing more gel particles and hence, more development in strength. The addition of SAP to concrete mix lead to decrease in compressive strength especially in early age, this reduction was associated with increase of capillary and gel porosity in the internally cured system because SAP expands after absorbing water, became a hydrogel and acted as voids in the cementation materials [3]. Many author think that the long- term compressive strength can be equal or higher than strength of references mixes [4]. This predicates that there is an increased hydration, leading to strong microstructure of concrete gives greater compressive strength [5].

\section{Expermintal Work 2.1 Materials}

2.1.1 Cement:- Ordinary Portland Cement used in this research was commercially available with the trade mark of (Tasloja). Table $1 \& 2$ included the physical and chemical properties of this cement respectively, which are conformed to Iraqi Standard Specification I.Q.S. No.5/ 1984 [6]. All tests have been completed at the National Center for Construction Laboratories and Research. 
Table 1 Physical properties of the cement.

\begin{tabular}{|c|c|c|}
\hline Physical Properties & $\begin{array}{c}\text { Test } \\
\text { Results }\end{array}$ & $\begin{array}{c}\text { Iraqi } \\
\text { specification } \\
\text { No. 5/1984 }\end{array}$ \\
\hline $\begin{array}{c}\text { Fineness using Blaine } \\
\text { air permeability } \\
\left.\text { apparatus(m } / \mathrm{m}^{2} / \mathrm{kg}\right)\end{array}$ & 405 & $230^{++}$ \\
\hline $\begin{array}{c}\text { Setting time using } \\
\text { Vicat's instruments } \\
\text { Initial(min.) } \\
\text { Final(hr) }\end{array}$ & 135 & $45^{*+}$ \\
\hline $\begin{array}{c}\text { Compressive strength } \\
\text { for cement Paste }\end{array}$ & $3: 25$ & $10^{+}$ \\
$\begin{array}{c}\text { Cube(70.7mm) at: } \\
\text { 3days(MPa) }\end{array}$ & 24.4 & $15^{*+}$ \\
7days(MPa) & 32.3 & $23^{*+}$ \\
\hline
\end{tabular}

* Maximum

\$* Minimum

Table 2 Chemical composition of the cement.

\begin{tabular}{|c|c|c|}
\hline $\begin{array}{l}\text { Chemical } \\
\text { composition }\end{array}$ & \%(weight) & $\begin{array}{c}\text { Iraqi specification } \\
\text { No. 5/1984 }\end{array}$ \\
\hline Lime $\mathrm{CaO}$ & 61.19 & - \\
\hline Silica $\mathrm{SiO}_{2}$ & 21.44 & - \\
\hline Alumina $\mathrm{Al}_{2} \mathrm{O}_{3}$ & 4.51 & - \\
\hline Iron Oxide $\mathrm{Fe}_{2} \mathrm{O}_{3}$ & 3.68 & - \\
\hline Magnesia $\mathrm{MgO}$ & 2.31 & 5 \\
\hline Sulfate $\mathrm{SO}_{3}$ & 2.7 & $2.8^{\circ}$ \\
\hline Loss on ignition L.O.I & 2.39 & $4.0^{\circ}$ \\
\hline Insoluble residue I.R & 1.18 & $1.5^{\circ}$ \\
\hline Lime saturation factor L.S.F & 0.87 & $0.66-1.02$ \\
\hline Tricalcium aluminates $\mathrm{C}_{2} \mathrm{~A}$ & 5.73 & - \\
\hline Tricalcium silicate $\mathrm{C}_{2} \mathrm{~S}$ & 42.83 & - \\
\hline Dicalcium silicate $\mathrm{C}_{2} \mathrm{~S}$ & 29.11 & - \\
\hline Teracalcium alumina ferrite $\mathrm{C}_{4} \mathrm{AF}$ & 11.2 & - \\
\hline
\end{tabular}

2.1.2 Fine Aggregate:- two type of fine aggregate have been used:-

a- Al-Ukhaider natural sand, grading and physical properties of this sand are conformed with the limits of the Iraqi Specifications No.45/1984 [7], as installed in Tables 3 \& 4.

b- Imported fine silica sand, it has grade particle $\leq 600 \mu \mathrm{m}$, this type of sand used with RPC and MRPC, the grading of this type shown in Table 5.

Table 3 Grading of fine aggregate.

\begin{tabular}{|c|c|c|}
\hline Sieve size & Passing \% & $\begin{array}{c}\text { Iraqi specification No. } \\
\mathbf{4 5 / 1 9 8 4} \text { for Zone(2) }\end{array}$ \\
\hline $4.75 \mathbf{m m}$ & 93 & $\mathbf{9 0 - 1 0 0}$ \\
\hline $2.7 \mathrm{~mm}$ & 83.4 & $\mathbf{7 5 - 1 0 0}$ \\
\hline $1.18 \mathrm{~mm}$ & 69 & $\mathbf{5 5 - 9 0}$ \\
\hline $600 \mu \mathrm{m}$ & 47.3 & $\mathbf{3 5 - 5 9}$ \\
\hline $300 \mu \mathrm{m}$ & 15.4 & $\mathbf{8 - 3 0}$ \\
\hline $150 \mu \mathrm{m}$ & 0.7 & $\mathbf{0 - 1 0}$ \\
\hline Pan & zero & Zero \\
\hline
\end{tabular}

Table 4 Physical properties of fine aggregate.

\begin{tabular}{|l|l|}
\hline Physical properties & Test result \\
\hline Specific gravity & 2.6 \\
\hline Sulfate content & $0.11 \%$ \\
\hline Absorption & $0.75 \%$ \\
\hline
\end{tabular}

Table 5 Grading of silica sand aggregate.

\begin{tabular}{|c|c|}
\hline Sieve size & Passing \% \\
\hline $600 \mu \mathrm{m}$ & 93 \\
\hline $300 \mu \mathrm{m}$ & 23 \\
\hline $150 \mu \mathrm{m}$ & 4.5 \\
\hline Pan & 0 \\
\hline
\end{tabular}

2.1.3 Coarse Aggregate (CA):- Crushed gravel used with size range (5-19) $\mathrm{mm}$ and $(\leq 12.5) \mathrm{mm}$ as a coarse aggregate used in this study, the grading of the coarse aggregate used and its physical properties conform to Iraqi Specifications No.45/1984 [7], and are presented in Tables $6,7 \& 8$ respectively. Sieve analyses of CA and fine aggregate has been done in construction laboratories of civil engineering department at college of engineering in Diyala University.

Table 6 Grading of coarse aggregate size (5-19mm).

\begin{tabular}{|c|c|c|}
\hline Sieve size (mm) & Passing \% & $\begin{array}{c}\text { Iraqi specification No. } \\
\mathbf{4 5 / 1 9 8 4} \text { for Zone(2) }\end{array}$ \\
\hline 20 & 95.559 & $95-100$ \\
\hline 10 & 31 & $30-60$ \\
\hline 5 & 0.771 & $0-10$ \\
\hline Pan & Zero & Zero \\
\hline
\end{tabular}

Table 7 Grading of coarse aggregate size $\leq 12.5 \mathrm{~mm}$.

\begin{tabular}{|c|c|c|}
\hline Sieve size (mm) & Passing \% & $\begin{array}{c}\text { Iraqi specification No. } \\
45 / 1984 \text { for Zone(2) }\end{array}$ \\
\hline 12.5 & 100 & $90-100$ \\
\hline 10 & 88.7 & $50-85$ \\
\hline 4.75 & 0.51 & $0-10$ \\
\hline Pan & Zero & zero \\
\hline
\end{tabular}

Table 8 Physical properties of coarse aggregate.

\begin{tabular}{|c|c|}
\hline Physical properties & Test result \\
\hline Specific gravity & 2.6 \\
\hline Sulfate content & $0.08 \%$ \\
\hline Absorption & $0.70 \%$ \\
\hline
\end{tabular}

2.1.4 Water:- Clean tap water from water supply system was used for mixing concrete and curing it.

2.1.5 Silica Fume:- Micro silica considered most reactive than any other natural pozzolana. To product HSC and UHSC need to improve the properties of material, in this research silica fume has become one of most important ingredients .The micro silica has $\mathrm{SiO}_{2}$ content at least $90 \%$ and mean particle size below 0.1 microns, it supplyl from SIKAl company. Table 9 presents the properties of silica fume. 
Table 9 Silica Fume Properties.

\begin{tabular}{|c|c|}
\hline Type & Densified Silica fume \\
\hline Form & powder \\
\hline Color & Gray \\
\hline Surface area & $24000-28000 \mathrm{~m} 2 / \mathrm{kg}$ \\
\hline SiO2 & $\geq 90 \%$ \\
\hline $\mathrm{SO3}$ & $\leq 0.2 \%$ \\
\hline $\mathrm{CaO}$ & $\leq 0.8 \%$ \\
\hline
\end{tabular}

2.1.6 Super Plastisezer (Glenium 51):- It is a new generation of super-plasticizing admixture based on chains of modified polycarboxylate ether. It is developed for applications concrete industries when it need highest durability, workability and performance concrete, this type of superplastisezer is free from chlorides and it is suitable with all type of cement and complies with ASTM C494-05(3) type (F). Table 10 presents the technical description of Glenium-51.

Table 10 Technical description of Glenium-51*.

\begin{tabular}{|c|c|}
\hline Form & Viscous liquid \\
\hline Color & Light brown \\
\hline Relative density & $1.1 @ 20$ \\
\hline $\mathrm{pH}$ & 6.6 \\
\hline Viscosity & $128+f-30$ CPS@20 \\
\hline Transport & Not classified as dangerous \\
\hline Labeling & No hazard label required \\
\hline \multicolumn{2}{|c|}{ * From Manufacturer Catalogue. }
\end{tabular}

2.1.7 Steel Fiber:- Hooked steel fibers with $50 \mathrm{~mm}$ length used throughout the experimental program, its density $7800 \mathrm{~kg} / \mathrm{m}^{3}$, diameter $0.8 \mathrm{~mm}$ and used for produce RPC and MRPC.

\subsubsection{Super Absorbent Polymer (SAP):-}

A smart material that used in this research represent by superabsorbent polymer (SAP)with white granules appearance and have ability to absorb water about $\geq 350$ (pure water, $\mathrm{ml} / \mathrm{g}$ ) and strong gel intensity, grinding it to ensure that small size not leave large pore in concrete paste. Its supply by Areej Al-Furat company. The properties of SAP installed in Table 11.

Table (11) Properties of Super Absorbent Polymer SAP.

\begin{tabular}{|c|c|}
\hline Sample name & Agricultural Grade SAP \\
\hline Appearance & White Gramules \\
\hline Water retention rate (purwater,ml/g) & $\geq 350$ \\
\hline Gel intensity & Strong \\
\hline Particle size (mesh) & $5-20$ mesh,20-80 mesh,30-100 \\
& mesh \\
\hline
\end{tabular}

2.1.9 Reinforcement Bar:- Steel bars with different diameters were used for reinforcing concrete beams, the diameter of bars are (16,

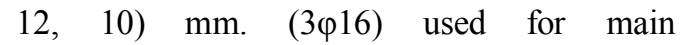
reinforcement, $(2 \varphi 12)$ used for secondary reinforcement and $(\varphi 10)$ used for stirrups, all these details are installed in Figure 1. All beams were designed to fail in flexural according to ACI 318-14 [8].

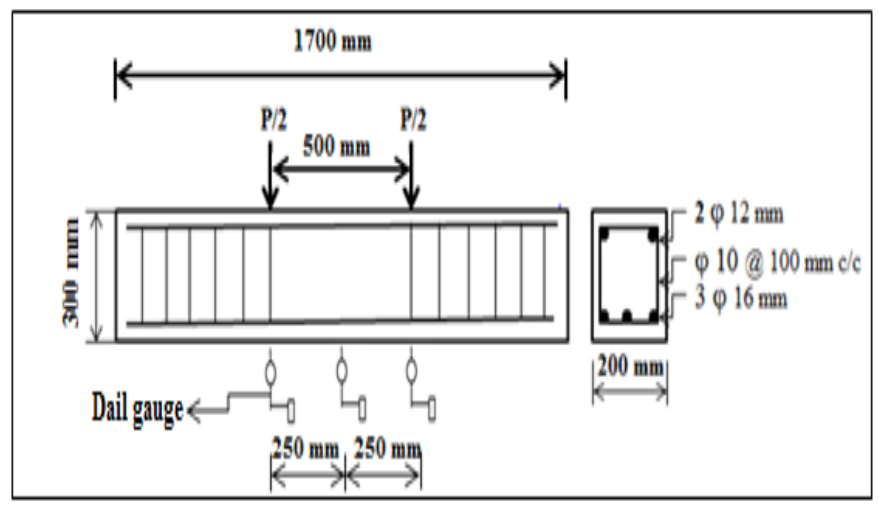

Figure 1: Dimension and reinforcement of beams

2.2 Casting and Curing:- Table 12 explain the properties of concrete used in this research for five mixes and their compressive strength are installed in Table 13, ten beams are divided into two groups. Group (A) has five beams casted without SAP while the another group (B) have five beams casted with the addition of SAP. The mixes were casting in ply- wood mold each one separately. After de-molded the specimens, wetted canvas used for curing the specimens for 28 days.

Table 12 Properties of concrete mixes.

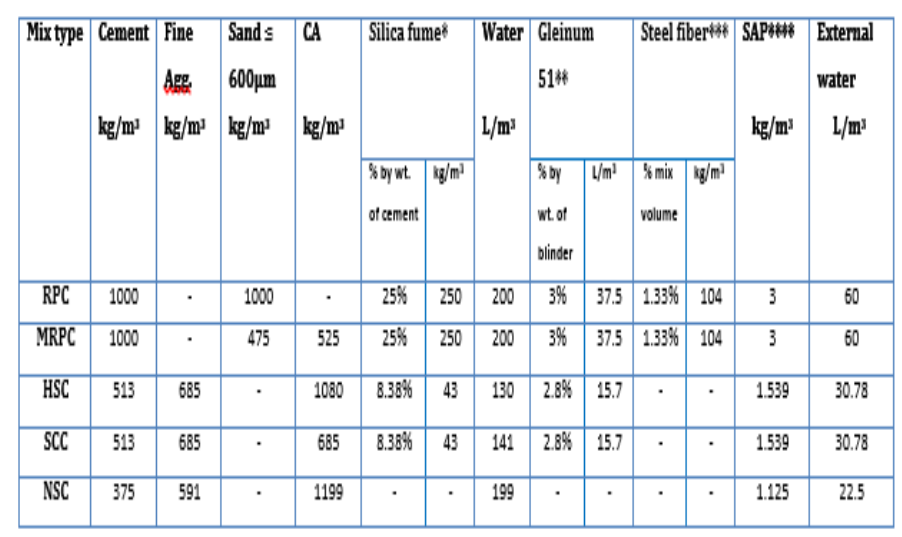

- \% \%y weight of cement

- $\$ * \%$ by weight of comentation materials (cementt silica fume)

- *** \% by mix wolume

- $\quad$ *\$8 $0.3 \%$ by weight of cement for all mixes

Table 13 Compressive strength of concrete mixes.

\begin{tabular}{|c|c|c|c|c|c|c|}
\hline \multirow{2}{*}{ Mix. Type } & \multicolumn{3}{|c|}{$\begin{array}{c}\text { Compressive strength } \\
\text { without SAP (fcu)/(MPa) }\end{array}$} & \multicolumn{3}{c|}{$\begin{array}{c}\text { Compressive strength with } \\
\text { SAP (fcu)/(MPa) }\end{array}$} \\
\cline { 2 - 7 } & 7 day & 28 day & 56 days & 7 day & 28 day & 56 days \\
\hline RPC & 120 & 154 & 175 & 80 & 145 & 180 \\
\hline MRPC & 96 & 112 & 132 & 64 & 102 & 139 \\
\hline SCC & 76 & 104 & 125 & 50 & 100 & 131 \\
\hline HSC & 78 & 110 & 140 & 70.5 & 105 & 147 \\
\hline NSC & 26.55 & 35.15 & 40 & 17 & 34 & 45 \\
\hline
\end{tabular}


2.3 Instroment:- Hydraulically universal testing machine with capacity (2000) $\mathrm{kN}$ and Dial Gauge with maximum measurement of (50) $\mathrm{mm}$ is placed in the midpoint of the bottom of beam and two dail gauge positioned at (250)mm from both sides of center (the maximum measurement of (30) $\mathrm{mm}$ ) as shown in Figure 1, all these tools used in test of beams.

2.4 Testing:- Simply supported beams were tested with over span of (1500) mm center to center of supports. Loads applied with two points, clear span between them (500) $\mathrm{mm}$. Relative thick rubber strips were inserted between the concrete and line loads to provide even surface, as well as between support of machine and lower support face of beams, two months the age of testing.

\section{Results and Discussion}

Figure 2 show the load-deflection behavior of beams that casting without SAP, it was clear that beam (B1) that casting with RPC concrete have higher ultimate load than other beams, this is because RPC have higher compressive strength that equal to (154) $\mathrm{MPa}$ at age 28 days, the ultimate carrying capacity of the beam has extrusive relationship with compressive strength of concrete. The values of deflection at ultimate loads obtained from the dial gauge readings are presented in Table 14. It was found that the deflection at ultimate load in all beams in group B was lower than the deflection in all beams in group $\mathrm{A}$ at $(9.4$ $\%, 8 \%, 20 \%, 23 \%$ and $12 \%$ ) for (B1, B 2, B 3, $\mathrm{B} 4$ and $\mathrm{B} 5$ ) respectively. The values of ultimate loads for all beams in group B are slightly higher than the ultimate load in group A for beams (1, 2, 3, 4 and 5) at $(1.5 \%, 1.8 \%$, $3 \%, 2.4 \%$ and $4.12 \%$ ) respectively. Figures 3 , 4, 5, 6 and 7 illustrates the load deflection curves of the specimens group (A and B),the increase in load might be due to improvement of the interfacial transition zone, enhanced hydration due to internal curing, internal curing (IC) increases degree of hydration by released the water from SAP to surrounding concrete, the increase in hydration degree of cement particle lead to a reduction of capillary porosity and producing a denser microstructure leading to more stiffness [9], then lead to increase the load and decrease the deflection.

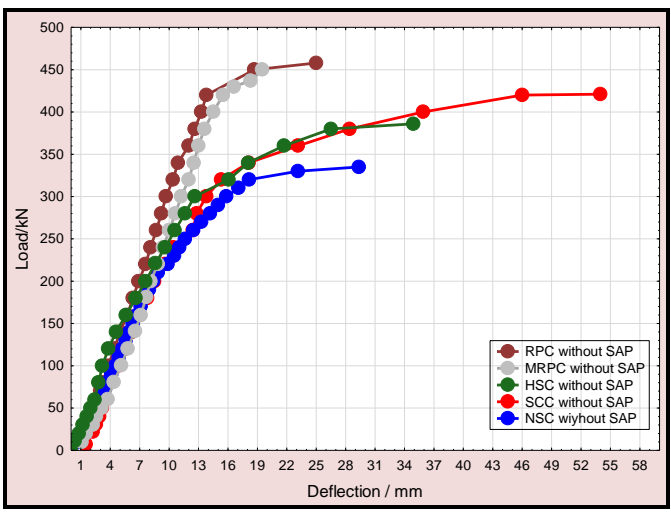

Figure 2: Load-Deflection behavior of beams without SAP group A

Table 14 Test results of beams of group (A and B).

\begin{tabular}{|c|c|c|c|c|}
\hline \multirow{2}{*}{$\begin{array}{l}\text { Beam no. } \\
\text { Mix type }\end{array}$} & \multicolumn{2}{|c|}{ Group A } & \multicolumn{2}{|c|}{ Group B } \\
\hline & $\begin{array}{l}\text { Ultimate load } \mathrm{P}_{\mathrm{u}} \\
(\mathrm{kN})\end{array}$ & $\begin{array}{l}\text { Ultumate deflection } \\
\qquad \Delta u(m m)\end{array}$ & $\begin{array}{l}\text { Ultimate load } \mathrm{P}_{\mathrm{e}} \\
(\mathrm{kNN})\end{array}$ & $\begin{array}{l}\text { Ultimate deflection } \\
\qquad \Delta u(\mathrm{~mm})\end{array}$ \\
\hline $\begin{array}{l}\text { Beam l } \\
\text { /RPC }\end{array}$ & 458 & 25 & 465 & 22.65 \\
\hline $\begin{array}{l}\text { Beam } 2 \\
\text { MRPC }\end{array}$ & 450 & 19.5 & 458 & 18 \\
\hline $\begin{array}{l}\text { Beam } 3 \\
\text { /HSC }\end{array}$ & 386 & 34.9 & 397 & 27.89 \\
\hline $\begin{array}{l}\text { Beam } 4 \\
\text { /SCC }\end{array}$ & 421 & 54 & 431 & 41.48 \\
\hline $\begin{array}{l}\text { Beam } 5 \\
\text { /NSC }\end{array}$ & 335 & 29.36 & 349 & 25.84 \\
\hline
\end{tabular}

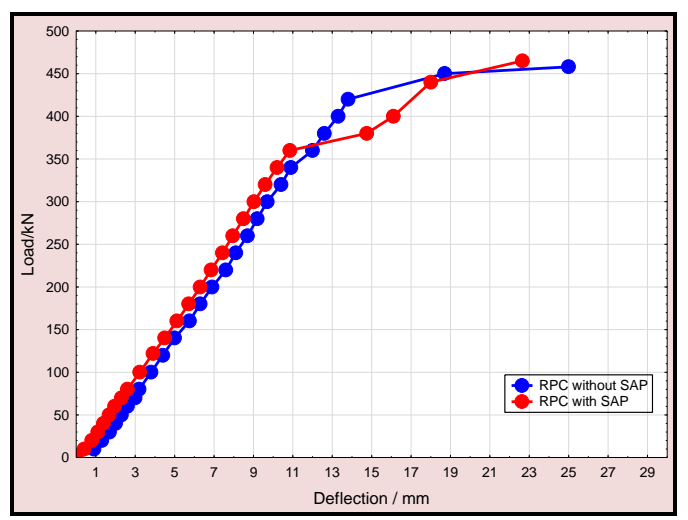

Figure 3: Load- Deflection curve of RPC beam 1 with and without SAP

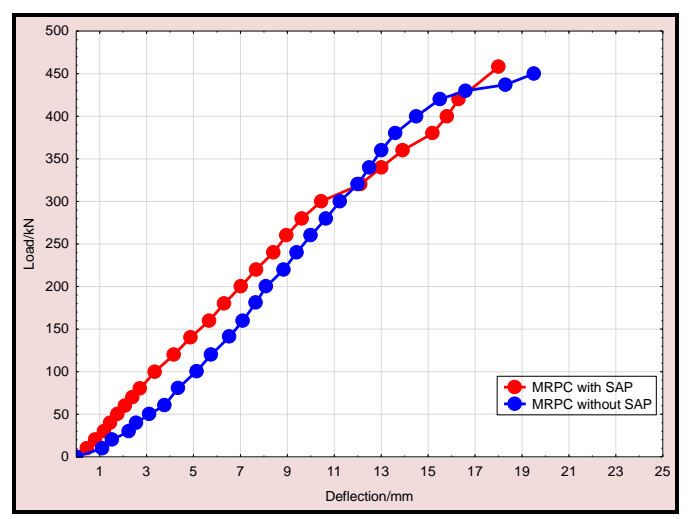

Figure 4: Load- deflection curve of MRPC beam 2 with and without SAP 


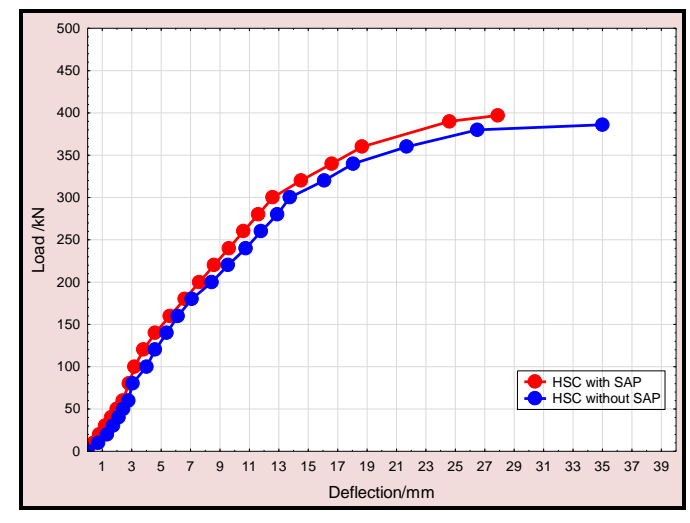

Figure 5: Load- Deflection curve of HSC beam 3 with and without SAP

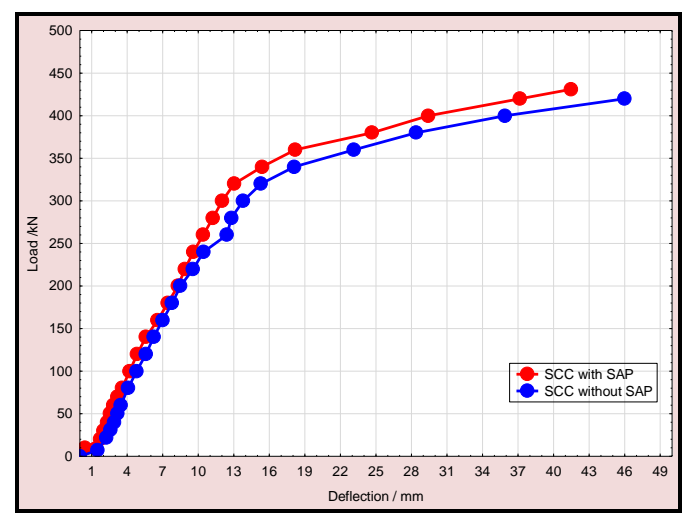

Figure 6: Load-Deflection curve of SCC beam 4 with and without SAP

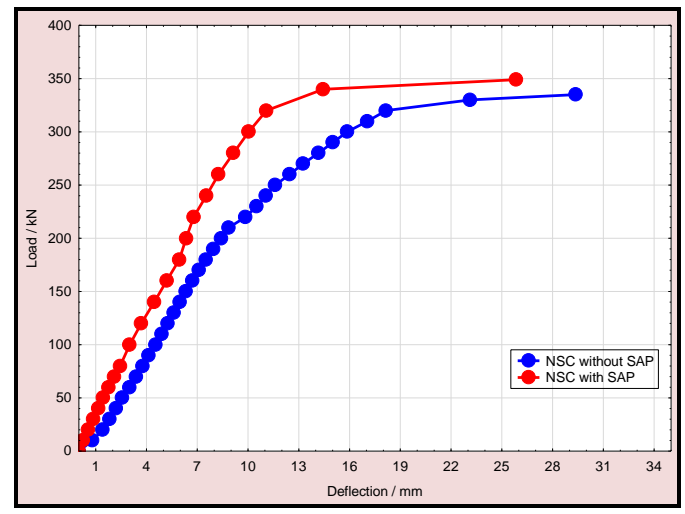

Figure 7:Load- Deflection curve of NSC beam 5 with and without SAP

\section{Concolusion}

On the basis of (10) beams produced from different concrete mixes, and tested for their load-deflection behavior of beams with and without SAP, the main conclusions can be summarized as follows:-

a- Beams casting with concrete have SAP particles and external water for internal curing had a slight effect on ultimate load of beams at group B by increasing load carrying capacity compared with beams casting without SAP as internal curing by $(1.5 \%, 1.8 \%, 3 \%, 2.4 \%$ and $4.1 \%$ ) for (B1, B 2, B 3,B 4 and B 5) respectively

b- The max deflection that results under ultimate load was decreased in beams that have SAP in its concrete with external water compared with beams without SAP, the percentage of reduction was $((9.4 \%, 8 \%, 20 \%$, $23 \%$ and $12 \%$ )for (B1, B 2, B 3,B 4 and B 5) respectively.

\section{References}

[1].Buchholz,F.L., \& Graham,A.T. Modren Superabsorbent Polymer Technolology. John.Wiley\& Sons,Inc, 605 Third Ave, New York,NY10016, USA, 1998, 279.

[2].Frank M., Superabsorbents. In: Bohnet M et al. Ulmann's Encyclopedia of Technical Chemistry, $7^{\text {th }}$ edn, electronic release.WileyVCH Verlag, 2003.

[3].Song, C., Choi,Y.C., \& Choi,S. Effect of internal curing by superabsorbent polymersInternal relative humidity and autogenous shrinkage of alkali-activated slag mortars. Construction and Building Materials, 123, (2016), 198-206

[4].Mechtcherine,V.\&Reinhardt,H.W.(Eds.). Application of super absorbent polymers(SAP) in concrete construction : state- of- the- art report prepared by Technical Committee 225SAP (vol.2), (2012), Springer Science \& Business Media

[5].Gifta,C.C., and et. al., Study on Internal Curing of High Performance Concrete using Superabsorbent Polymers and Light Weight Aggregate.Asian Journal of Civil Engineering (BHRC), 14(5), (2013), 773-781.

[6].Iraqi Specification No. 5, Portland Cement, Baghdad, Iraq, 1984.

[7].Iraqi Specification No. 45, Natural Sources for Gravel that is Used in Concrete and Construction, Baghdad, Iraq, 1984.

[8].American Concrete Institute, ACI Committee 318, Building Code Requirements for Structural Concrete and Commentary, ACI 318M-02/ACI 318RM-05, 2014, 109-157.

[9].Viktor, M.,\&Hans-Wolf, R. Application of Super Absorbent Polymers (SAP)in concrete Construction.RILEM State-of-the-Art

Reports,2, (2012), 13-134 